\title{
Development of a validated HPLC method for simultaneous determination of olanzapine and aripiprazole in human plasma
}

\author{
Sakine ATILA KARACA *, Duygu YENICELII UĞUR
}

Department of Analytical Chemistry, Faculty of Pharmacy, Anadolu University, 26470 Eskişehir, Turkey.

* Corresponding Author. E-mail: sakineatila@anadolu.edu.tr (S.A.K.); Tel. +90 2223350580 / 37 65; ORCID No: 0000-0002-9440-3438.

Received: 02 February 2018 / Revised: 03 April 2018 / Accepted: 17 April 2018

\begin{abstract}
A simple and rapid HPLC method was developed and validated for simultaneous determination of two antipsychotic drugs, olanzapine and aripiprazole, in spiked human plasma. Optimization studies were performed using experimental design approach. The most important analysis parameters were selected using fractional factorial design and optimum levels of these parameters were determined with Box-Behnken design. Separation was achieved on a monolithic column (Rp-18, 100-4.6 mm) set at $35^{\circ} \mathrm{C}$ with a flow rate of $0.8 \mathrm{ml} / \mathrm{min}$. Gradient elution was performed with a mobile phase consisting of phosphate buffer $(\mathrm{pH} 3.14,20 \mathrm{mM})$ and acetonitrile. Retention times of olanzapine and aripiprazole were 2.34 and 6.90 minutes, respectively. The method was linear in the range of $0.125-50.0 \mu \mathrm{g} / \mathrm{ml}$ for olanzapine and $0.500-50.0 \mu \mathrm{g} / \mathrm{ml}$ for aripiprazole. The quantification limits for olanzapine and aripiprazole were found 0.069 and $0.498 \mu \mathrm{g} / \mathrm{ml}$, respectively. The method was found accurate and precise based on recovery values, which were between $99-102 \%$ and relative standard deviations, which were lower than $2 \%$. Robustness of the method and the stability of analytes were also investigated.
\end{abstract}

KEYWORDS: Olanzapine; aripiprazole; HPLC; determination; experimental design; human plasma.

\section{INTRODUCTION}

Schizophrenia is a chronic and severe psychiatric condition characterized with psychosis, inactivity, lack of motivation and cognitive disorders [1]. Antipsychotic drugs are used for the treatment of schizophrenia as a first choice. Antipsychotic drugs are classified as typical and atypical antipsychotics. Atypical ones, which are developed recently, show their effects by blocking $5-\mathrm{HT}_{2} \mathrm{~A}$ receptors and they have less affinity to $\mathrm{D}_{2}$ receptors compared to typical ones. Affinity profiles for other receptors depend on the drug. Drugs in the atypical group are much more effective at negative symptoms and cognitive disorders of schizophrenia and they are less likely to cause tardive dyskinesia and extrapyramidal side effects compared to typical antipsychotics. On the other hand, atypical ones have risk of developing obesity, high blood glucose and cholesterol levels, and metabolic syndrome due to high blood pressure [2].

Recently, the combined use of different antipsychotic drugs has been tried for treatment of drugresistant schizophrenia patients. Combinations of antipsychotics with antidepressants; anticonvulsants with lithium; and the use of antipsychotics in combination with each other become a common practice in clinics although treatment guides suggest monotherapy [3]. One of this combination approaches is the addition of aripiprazole to olanzapine treatment to prevent dose-related side effects of olanzapine. Chemical structures of these molecules can be seen at Figure 1. Aripiprazole, which is an atypical antipsychotic drug approved in 2002 by FDA, is effective in positive and negative symptoms of schizophrenia. Its major advantages are lower risk for weight gain, increased lipid or prolactin levels, extrapyramidal side effects and sedation in comparison with typical and other atypical antipsychotics [4]. Another atypical antipsychotic, olanzapine has been used in the treatment of schizophrenia since 1996. It has advantages like lower risk for extrapyramidal side effects and minimal increase in prolactin levels. However, olanzapine has the risk for weight gain and elevated levels of insulin, leptin, and blood lipids in comparison with typical and other atypical antipsychotics [4].

How to cite this article: Atila Karaca S, Yeniceli Uğur D. Development of a validated HPLC method for simultaneous determination of olanzapine and aripiprazole in human plasma. Marmara Pharm J. 2018; 22 (4): 493-501. 
There are many reports in the literature about the combined use of olanzapine and aripiprazole [5-10]. As an example, Duggal reported the first case about this combination [5]. He observed a significant improvement in negative symptoms by the addition of aripiprazole to the treatment of a schizophrenic patient who had a partial response to olanzapine alone. Chen et al. reported two successful cases about the reduction of obesity and metabolic disturbance during the treatment of olanzapine with the administration of aripiprazole [6]. In these case reports, it appears that the addition of aripiprazole to olanzapine treatment to avoid the dose-related side effects seems to give positive results. However, the mechanism of this effect has not been fully understood yet.
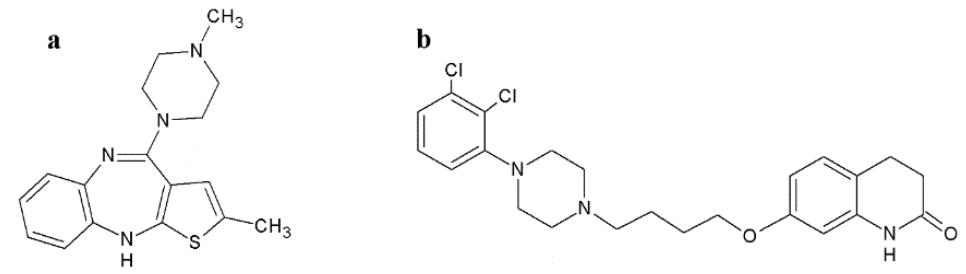

Figure 1. Chemical structures of olanzapine (a) and aripiprazole (b).

The quantification of antipsychotics in biological matrices is important for therapeutic and forensic purposes [11]. In literature, a few methods were reported for the determination of olanzapine in plasma or serum samples using HPLC with UV detection [12-14]. Similarly, there are a number of methods for the determination of aripiprazole in plasma or serum samples using HPLC with UV detection [15-17]. In addition, several LC-MS methods developed for the determination of various antipsychotics including aripiprazole and olanzapine in plasma or serum samples were reported [18-22]. According to our knowledge, there is no HPLC method for the co-analysis of these two active substances.

Experimental design is being widely used for optimizing analytical methods. In this approach multivariate data are fitted to a linear or quadratic function in order to provide information about a system. Statistical theory is used to choose the values of each factor to optimize investigated responses [23]. Experimental design has advantages such as valid results and also time, effort and resource saving when compared to traditional univariate procedures [24].

The aim of this study is to develop an effective, simple and rapid HPLC method for simultaneously quantification of olanzapine and aripiprazole. Experimental design was used during the method development for a faster and easier optimization process compared with the univariate procedures. The separation of analytes was performed on a monolithic column considering its superior performance for fast separations with low pressure. An internal standard was used to get improved precision and accuracy for the quantification. Finally, developed method was validated according to the International Conference on Harmonization guideline [25]. Considering the advantages of HPLC, the development of a HPLC method for the simultaneous analysis of these two antipsychotic drugs is considered an important contribution to the literature.

\section{RESULTS}

\subsection{Method optimization}

Initially some preliminary studies were performed using a $20.0 \mu \mathrm{g} / \mathrm{ml}$ olanzapine and $20.0 \mu \mathrm{g} / \mathrm{ml}$ aripiprazole solution. Acetonitrile was selected as organic solvent and carbamazepine as internal standard during these studies. It was decided to use gradient elution due to very different retention times of olanzapine and aripiprazole. Studies were performed using a Chromolith High Resolution (Rp-18, 100-4.6 mm) column.

The fractional factorial design were used to investigate the importance of factors on responses. $\mathrm{pH}$, buffer concentration, initial and final percentage of acetonitrile in gradient program, gradient time, flow rate and column temperature were selected as factors. Factors and their levels at fractional factorial design were given in Table 1. Their effects on six different responses, retention factors and tailing factors of two analytes and resolutions of following peaks ( $\mathrm{K}_{\mathrm{OLA}}, \mathrm{K}_{\mathrm{ARI}}, \mathrm{T}_{\mathrm{OLA}}, \mathrm{T}_{\mathrm{ARI}}, \mathrm{R}_{1}, \mathrm{R}_{2}$ ), were investigated. Experiments were performed in random order according to the plan defined by fractional factorial design. Experimental design and data analysis were done using Minitab 17. Coefficients of response model can be seen in Table 2. pH, buffer concentration and initial percent of acetonitrile were selected as most important factors because only the model terms with corresponding p-value less than 0.05 are significant at $95 \%$ confidence level and they have effect on more than one response. Optimum values of other factors were determined considering separations, retention times and peak morphologies of the analytes. 50\% acetonitrile was chosen as final 
percentage of acetonitrile in 5 minutes of gradient program and also flow rate and column temperature were set at $0.8 \mathrm{ml} / \mathrm{min}$ and $35^{\circ} \mathrm{C}$, respectively.

Table 1. Factor and levels for fractional factorial design and Box-Behnken design.

\begin{tabular}{lllll}
\hline \multirow{2}{*}{ Experimental design } & Factors & \multicolumn{3}{c}{ Levels } \\
& & -1 & 0 & +1 \\
\hline & $\mathrm{pH}$ & 3.0 & 4.5 & 6.0 \\
& Buffer concentration & 10 & 20 & 30 \\
& Initial percent of ACN & 20 & 25 & 30 \\
Fractional factorial design & Final percent of ACN & 40 & 45 & 50 \\
& Gradient time & 3 & 4 & 5 \\
& Flow rate & 0.8 & 0.9 & 1.0 \\
& Temperature & 25 & 30 & 35 \\
\hline \multirow{3}{*}{ Box-Behnken design } & pH (x1) & 3.0 & 4.0 & 5.0 \\
& Buffer concentration (x2) & 10 & 15 & 20 \\
& Initial percent of CAN (x3) & 20 & 25 & 30 \\
\hline
\end{tabular}

ACN: Acetonitrile

Table 2. Calculated coefficients for fractional factorial design.

\begin{tabular}{lcccccc}
\hline Coefficients & $\mathrm{K}_{\text {OLA }}$ & $\mathrm{K}_{\text {ARI }}$ & $\mathrm{T}_{\text {OLA }}$ & $\mathrm{T}_{\text {ARI }}$ & $\mathrm{R}_{1}$ & $\mathrm{R}_{2}$ \\
\hline Constant & $2.325^{*}$ & $8.311^{*}$ & $1.5713^{*}$ & $1.2484^{*}$ & $15.95^{*}$ & $15.00^{*}$ \\
$\mathrm{pH}$ & $1.643^{*}$ & $3.952^{*}$ & 0.1457 & 0.0358 & $-13.72^{*}$ & $8.55^{*}$ \\
Buffer concentration & $-0.248^{*}$ & -0.729 & $-0.2124^{*}$ & -0.0277 & 0.38 & 0.84 \\
Initial percent of ACN & $-0.415^{*}$ & 0.667 & 0.1012 & 0.0214 & $-2.52^{*}$ & $3.40^{*}$ \\
Final percent of ACN & -0.110 & $-1.504^{*}$ & -0.0404 & 0.0110 & -0.63 & -0.23 \\
Gradient time & 0.107 & 0.311 & -0.0175 & 0.0073 & 0.98 & 0.94 \\
Flow rate & 0.059 & 0.467 & $0.2033^{*}$ & 0.0101 & -0.71 & -0.45 \\
Temperature & 0.098 & -0.961 & -0.0028 & -0.0300 & -0.43 & -2.32 \\
\hline
\end{tabular}

Kola: Retention factor of olanzapine; $\mathrm{K}_{\text {ARI: }}$ Retention factor of aripiprazole; TolA: Tailing factor of olanzapine; $\mathrm{T}_{\text {ARI: }}$ Tailing factor of aripiprazole; $R_{1}$ : Resolution between olanzapine and carbamazepine; $R_{2}$ : Resolution between carbamazepine and aripiprazole, ACN: Acetonitrile. ${ }^{*}$ Coefficients significant for $\mathrm{p}$-value $<0.05$.

Box-Behnken design was used to optimize the selected factors. Factors and their levels at Box-Behnken design were given in Table 1. After performing appropriate experiments in random order according to the plan defined by Box Behnken design, data analysis were done using Minitab 17. As seen in Table 3, effects of all three factors were found to be significant on most responses. Derringer's desirability function was used to optimize four responses (retention factors and tailing factors of two analytes) simultaneously. Each response was transformed to a desirability function using equations given below (Equation 1-3). Equation 1, 2 or 3 were selected depending on the target value for the response which is a maximum or minimum value or located between a lower and upper limit, respectively. Overall desirability (D) was calculated by geometrical mean of individual desirability functions. Desirability functions have a value between 0 , for a completely undesirable response, and 1, for a fully desired response. Then, calculations were made using overall desirability as only response. Coefficients of response model for overall desirability function can be seen in Table 3.

$$
d=\left\{\begin{array}{cc}
0 & \text { if } Y_{i} \leq L_{i} \\
{\left[\frac{Y_{i}-L_{i}}{T_{i}-L_{i}}\right]^{s}} & \text { if } L_{i}<Y_{i} \leq T_{i} \\
0 & \text { if } Y_{i} \geq T_{i}=U_{i}
\end{array}\right\} \quad d=\left\{\begin{array}{cc}
1 & \text { if } Y_{i} \leq T_{i}=L_{i} \\
{\left[\frac{Y_{i}-U_{i}}{T_{i}-U_{i}}\right]^{s}} & \text { if } U_{i}<Y_{i} \leq T_{i} \\
0 & \text { if } Y_{i} \geq U_{i}
\end{array}\right\} \quad d=\left\{\begin{array}{ll}
{\left[\frac{Y_{i}-L_{i}}{T_{i}-L_{i}}\right]^{s}} & \text { if } L_{i} \leq Y_{i} \leq T_{i} \\
{\left[\frac{Y_{i}-U_{i}}{T_{i}-U_{i}}\right]^{t}} & \text { if } T_{i}<Y_{i}<U_{i} \\
0 & \text { if } Y_{i}<L_{i} \text { or } Y_{i}>U_{i}
\end{array}\right\}
$$

(2)
(3) 
$L_{i}$ is lower value, $U_{i}$ is upper value and $T_{i}$ is target value that is desired for the response $Y_{i} . s$ and $t$ are the weights and when they are equal to 1, the desirability function is linear [26].

Table 3. Calculated coefficients for Box-Behnken design.

\begin{tabular}{lccccc}
\hline Coefficients & KOLA $_{\text {O }}$ & $\mathrm{K}_{\text {ARI }}$ & $\mathrm{T}_{\text {OLA }}$ & $\mathrm{T}_{\text {ARI }}$ & $\mathrm{D}$ \\
\hline b0 & $1.2522^{*}$ & $4.3957^{*}$ & $1.8903^{*}$ & $1.3132^{*}$ & $0.5339^{*}$ \\
b1 & $0.8782^{*}$ & $0.7478^{*}$ & $0.2241^{*}$ & $0.0973^{*}$ & -0.0469 \\
b2 & -0.0322 & $-0.0320^{*}$ & $-0.1058^{*}$ & 0.0009 & $0.0631^{*}$ \\
b3 & $-0.4534^{*}$ & $-0.4653^{*}$ & -0.0588 & -0.0321 & 0.0244 \\
b11 & $0.1903^{*}$ & $0.4767^{*}$ & $-0.1976^{*}$ & -0.0441 & $-0.1092^{*}$ \\
b22 & $0.0724^{*}$ & -0.0037 & 0.2111 & $-0.0661^{*}$ & 0.0311 \\
b33 & $0.0969^{*}$ & $-0.1025^{*}$ & -0.0447 & 0.0576 & -0.0597 \\
b12 & -0.0061 & -0.0184 & -0.0382 & -0.0541 & 0.0640 \\
b13 & $-0.2610^{*}$ & $0.0749^{*}$ & 0.0540 & $-0.0759^{*}$ & $0.1789^{*}$ \\
b23 & 0.0161 & -0.0025 & -0.0079 & -0.0049 & -0.0443 \\
R ${ }^{2} \mathrm{D}$ & 0.9990 & 0.9995 & 0.9223 & 0.9354 & 0.8617 \\
Adj. R ${ }^{2} \mathrm{D}$ & 0.9973 & 0.9985 & 0.7823 & 0.8192 & 0.8510 \\
\hline
\end{tabular}

KoLA: Retention factor of olanzapine; KARI: Retention factor of aripiprazole; ToLA: Tailing factor of olanzapine; $\mathrm{T}_{\text {ARI: }}$ Tailing factor of aripiprazole; D: Overall desirability, $R^{2} \mathrm{D}$ : Determination coefficient, Adj. $\mathrm{R}^{2} \mathrm{D}$ : Adjusted determination coefficient.

${ }^{*}$ Coefficients significant for $\mathrm{p}$-value $<0.05$.

In order to find overall desirability's determination coefficient $\left(R_{D}^{2}\right)$, predicted responses, predicted individual desirability functions and predicted overall desirability functions were calculated. Equations 4 and 5 were used to calculate $R_{D}^{2}$ and adjusted $R_{D}^{2}$ values.

$$
R_{D}^{2}=1-\frac{S S E}{S S T O}=1-\frac{\sum\left(D-D_{\text {pred }}\right)^{2}}{\sum(D-\bar{D})^{2}}
$$

$$
\operatorname{Adj.} R_{D}^{2}=1-\frac{S S E}{S S T O}=1-\frac{\sum\left(D-D_{\text {pred }}\right)^{2} /(N-2)}{\sum(D-\bar{D})^{2} /(N-1)}
$$

(2)

SSE is the sum of squares due to error, SSTO is the total sum of squares, $D_{\text {pred }}$ is the predicted D value for each case and $\bar{D}$ is the mean of $\mathrm{D}$ values. High $R_{D}^{2}$ and adjusted $R_{D}^{2}$ values, which were found as 0.8617 and 0.8510 , respectively, indicate the goodness-of-fit for this model.

Optimal conditions were found using Minitab 17 response optimizer and confirmed with the surface and counter plot graphics (Figure 2). From these results, $\mathrm{pH} 3.14,20 \mathrm{mM}$ buffer concentration and 20\% initial acetonitrile concentration were predicted as optimal. Finally, an analysis was performed at theoretically optimal conditions (Figure 3c) and appropriate retention times and peak symmetries with good resolution were obtained.

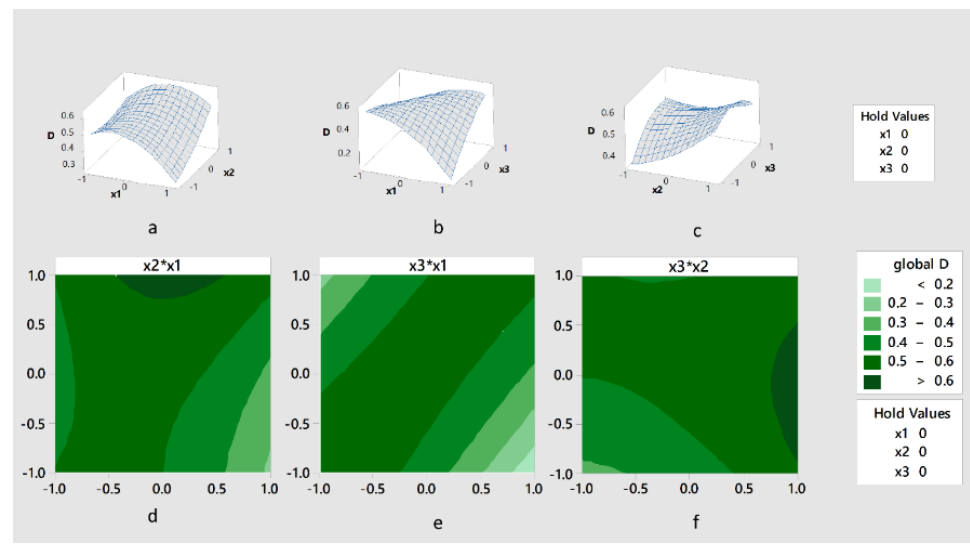

Figure 2. Counter plot and surface plot graphics: (a and d) $D($ desirability $)=f$ (buffer concentration $(x 2), p H$ of the mobile phase $(x 1))$; (b and e) $\mathrm{D}$ (desirability) $=f$ (initial percent of acetonitrile $(x 3), \mathrm{pH}$ of the mobile phase (x1)); (c and f) $\mathrm{D}$ (desirability) $=f$ (initial percent of acetonitrile (x3) and buffer concentration $(\mathrm{x} 2)$ ). 


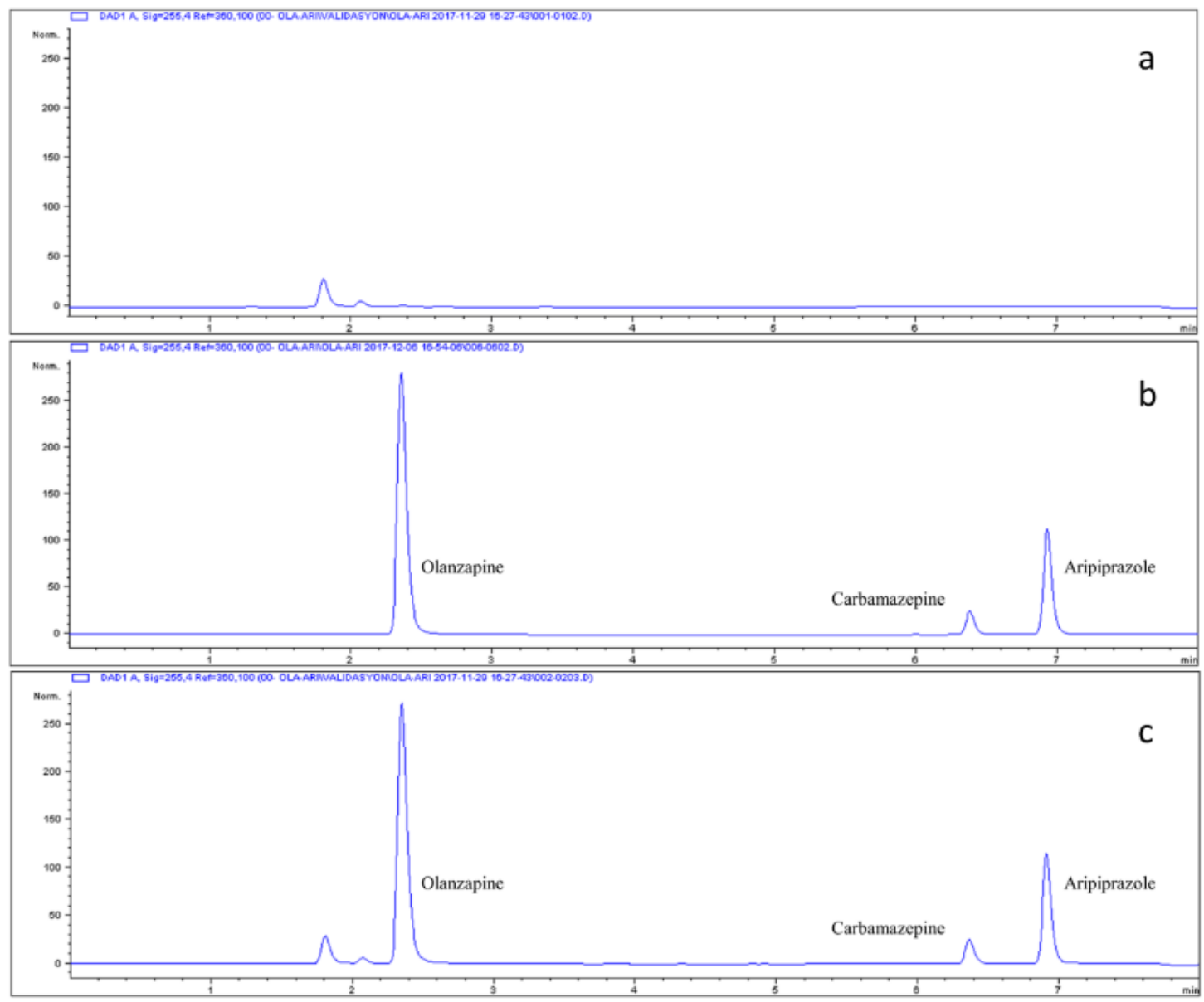

Figure 3. Chromatograms of blank plasma (a), standard solution (containing $48.0 \mu \mathrm{g} / \mathrm{ml}$ olanzapine, 48.0 $\mu \mathrm{g} / \mathrm{ml}$ aripiprazole and $10.0 \mu \mathrm{g} / \mathrm{ml}$ carbamazepine $(\mathrm{b})$, quality control solution (containing $48.0 \mu \mathrm{g} / \mathrm{ml}$ olanzapine, $48.0 \mu \mathrm{g} / \mathrm{ml}$ aripiprazole and $10.0 \mu \mathrm{g} / \mathrm{ml}$ carbamazepine. Mobile phase: phosphate buffer $(\mathrm{pH}$ 3.14 and $20 \mathrm{mM}$ ) (A) and acetonitrile (B); flow rate $0.8 \mathrm{ml} / \mathrm{min}$; column temperature $35^{\circ} \mathrm{C}$; detection wavelength $255 \mathrm{~nm}$.

\subsection{Method validation}

System suitability was assessed by seven replicated analyses of quality control solution at middle concentration. The system suitability parameters were given in Table 4. All parameters were found acceptable as seen in the table.

The developed method was validated according to the recommendations of International Conference on Harmonization guideline Q2R1 [25]. Specificity, linearity, accuracy and precision, detection and quantitation limits and robustness of the developed method were investigated. Besides, the stability of analytes was shown.

The specificity of the method was assessed by comparing the chromatograms of blank plasma and quality control solutions (Figure 3a, 3c). No interfering peaks were observed in retention times of analytes at the chromatogram of blank plasma (Figure 3a). The matrix effect was assessed by comparing responses of quality control solutions with standard solutions as references (Figure 3b). Peak area ratios for quality control solutions versus standard solutions were found between 99 and $102 \%$. Thus, no matrix effect was observed.

In order to investigate the linearity of the method, the calibration curves were constructed using different concentrations ranging from 0.125 to $50.0 \mu \mathrm{g} / \mathrm{ml}$ for both of the analytes. The method was linear in the range of $0.125-50.0 \mu \mathrm{g} / \mathrm{ml}$ for olanzapine and $0.500-50.0 \mu \mathrm{g} / \mathrm{ml}$ for aripiprazole. Signal to noise ratio of 3:1 and 10:1 were used to estimate the detection and quantitation limits, respectively. Obtained calibration equations, coefficients of determination $\left(\mathrm{R}^{2}\right)$, the limits of detection and quantitation are summarized in Table 5. 
Table 4. System suitability parameters $(6.00 \mu \mathrm{g} / \mathrm{ml}$ Olanzapine and $6.00 \mu \mathrm{g} / \mathrm{ml}$ Aripiprazole, $\mathrm{n}=7)$

\begin{tabular}{lccc}
\hline \multirow{2}{*}{ Parameters } & \multicolumn{2}{c}{ Observed value } & \multirow{2}{*}{ Requested value } \\
\cline { 2 - 3 } & Olanzapine & Aripiprazole & - \\
Retention time (min) & 2.34 & 6.90 & $2-10$ \\
Retention factor (k) & 0.88 & 4.53 & $\leq 2$ \\
Tailing factor (T) & 1.40 & 1.18 & $>2$ \\
Resolution (Rs) & $33.48\left(\mathrm{R}_{1}\right)$ & $4.85\left(\mathrm{R}_{2}\right)$ & $<1$ \\
RSD (\%) of retention time & 0.06 & 0.02 & $<1$ \\
RSD (\%) of peak area & 0.12 & 0.54 & \\
\hline
\end{tabular}

$\mathrm{R}_{1}$ : Resolution between olanzapine and carbamazepine, $\mathrm{R}_{2}$ : Resolution between carbamazepine and aripiprazole, RSD: Relative standard deviation.

Table 5. Linearity data.

\begin{tabular}{cccccc}
\hline Analytes & Range $(\mu \mathrm{g} / \mathrm{ml})$ & Regression equation & $\mathrm{R}^{2}$ & $\mathrm{LOD}(\mu \mathrm{g} / \mathrm{ml})$ & $\mathrm{LOQ}(\mu \mathrm{g} / \mathrm{ml})$ \\
\hline Olanzapine & $0.125-50.0(\mathrm{n}=9)$ & $\mathrm{y}=0.2367 \mathrm{x}+0.0136$ & 0.9999 & 0.021 & 0.069 \\
Aripiprazole & $0.500-50.0(\mathrm{n}=7)$ & $\mathrm{y}=0.0878 \mathrm{x}-0.0087$ & 0.9998 & 0.150 & 0.498 \\
\hline
\end{tabular}

$\mathrm{R}^{2}$ : Coefficient of determination, LOD: Limit of detection, LOQ: Limit of quantitation.

The accuracy, intra and interday precision of the developed method were evaluated by seven replicated analyses of quality control solutions. As seen in Table 6, accuracy and precision were expressed as relative error and relative standard deviation, respectively. The method was found accurate based on recovery values, which were between $99-102 \%$. The low relative standard deviations (lower than 2\%) indicate a good method precision.

Table 6. Accuracy and precision data.

\begin{tabular}{lccccc}
\hline \multirow{2}{*}{ Added Concentration $(\mu \mathrm{g} / \mathrm{ml})$} & \multicolumn{2}{c}{ Intraday $(\mathrm{n}=7)$} & \multicolumn{2}{c}{ Interday $(\mathrm{n}=21)$} \\
& & Recovery $(\%)$ & RSD $(\%)$ & Recovery $(\%)$ & RSD $(\%)$ \\
\hline \multirow{2}{*}{ Olanzapine } & 0.75 & 101.75 & 1.0418 & 101.91 & 1.1200 \\
& 6.00 & 99.51 & 0.1921 & 99.11 & 0.3424 \\
\multirow{2}{*}{ Aripiprazole } & 48.0 & 99.76 & 0.2424 & 100.84 & 0.7911 \\
\hline & 0.75 & 101.46 & 1.6715 & 101.41 & 1.3772 \\
& 6.00 & 99.54 & 0.6981 & 99.40 & 1.1331 \\
& 48.0 & 101.73 & 0.6056 & 101.88 & 0.5532 \\
\hline
\end{tabular}

RSD: Relative standard deviation.

The robustness of the method was investigated performing analyses under intentionally modified chromatographic conditions. Small changes were made in buffer concentration, $\mathrm{pH}$ and flow rate of mobile phase and column temperature. Recoveries were calculated in these new conditions. Recoveries which are between 98 and 102\% and small changes in retention times indicate the robustness of the method (Table 7). 
Table 7. Robustness data.

\begin{tabular}{lccccc}
\hline \multirow{2}{*}{ Parameter } & & \multicolumn{2}{c}{ Olanzapine } & \multicolumn{2}{c}{ Aripiprazole } \\
& & $\begin{array}{c}\text { Recovery } \\
(\%)\end{array}$ & $\begin{array}{c}\text { Retention } \\
\text { time }(\mathrm{min})\end{array}$ & $\begin{array}{c}\text { Recovery } \\
(\%)\end{array}$ & $\begin{array}{c}\text { Retention } \\
\text { time }(\mathrm{min})\end{array}$ \\
\hline \multirow{2}{*}{ Buffer concentration $(\mathrm{mM})$} & 18 & 99.18 & 2.376 & 100.86 & 6.936 \\
$\mathrm{pH}$ & 22 & 98.30 & 2.359 & 99.00 & 6.913 \\
& 3.04 & 98.51 & 2.328 & 100.55 & 6.929 \\
Flow rate $(\mathrm{ml} / \mathrm{min})$ & 3.24 & 100.49 & 2.422 & 101.37 & 6.940 \\
& 0.7 & 98.74 & 2.687 & 100.44 & 7.513 \\
Column temperature $\left({ }^{\circ} \mathrm{C}\right)$ & 0.9 & 100.81 & 2.115 & 100.12 & 6.465 \\
& 33 & 100.71 & 2.366 & 101.93 & 6.956 \\
\hline
\end{tabular}

The stability of analytes were also investigated using quality control solutions which were stored at room temperature for 24 hours or at $-20^{\circ} \mathrm{C}$ for two weeks or were exposed to three freeze thaw cycles for this purpose. The analytes were stable under all conditions according to calculated recoveries seen in Table 8 .

Table 8. Stability data.

\begin{tabular}{|c|c|c|c|c|c|c|c|}
\hline \multirow{2}{*}{\multicolumn{2}{|c|}{$\begin{array}{l}\text { Added Concentration } \\
\qquad(\mu \mathrm{g} / \mathrm{ml})\end{array}$}} & \multicolumn{2}{|c|}{$\begin{array}{c}\text { Short-term stability } \\
\text { (24 h, room temperature) }\end{array}$} & \multicolumn{2}{|c|}{$\begin{array}{l}\text { Long-term stability } \\
\left(2 \text { weeks, }-20^{\circ} \mathrm{C}\right)\end{array}$} & \multicolumn{2}{|c|}{$\begin{array}{c}\text { Freeze-thaw stability } \\
\text { (3 cycles) }\end{array}$} \\
\hline & & $\begin{array}{c}\text { Recovery } \\
(\%)\end{array}$ & $\begin{array}{c}\text { RSD } \\
(\%)\end{array}$ & $\begin{array}{c}\text { Recovery } \\
(\%)\end{array}$ & $\begin{array}{c}\text { RSD } \\
(\%)\end{array}$ & $\begin{array}{c}\text { Recovery } \\
(\%)\end{array}$ & $\begin{array}{c}\text { RSD } \\
(\%)\end{array}$ \\
\hline \multirow{3}{*}{ Olanzapine } & 0.75 & 98.67 & 0.4041 & 97.01 & 0.1332 & 99.88 & 0.3915 \\
\hline & 6.00 & 98.58 & 0.2273 & 98.78 & 0.1991 & 98.34 & 0.2763 \\
\hline & 48.0 & 101.24 & 0.1914 & 97.26 & 0.7940 & 100.74 & 0.2102 \\
\hline \multirow{3}{*}{ Aripiprazole } & 0.75 & 99.31 & 0.7195 & 100.27 & 0.3934 & 98.97 & 0.5995 \\
\hline & 6.00 & 98.83 & 0.1464 & 96.44 & 0.1523 & 99.49 & 0.2952 \\
\hline & 48.0 & 99.61 & 0.0771 & 91.53 & 0.8782 & 98.82 & 0.1616 \\
\hline
\end{tabular}

RSD: Relative standard deviation.

\section{CONCLUSION}

In this study, a HPLC method for the simultaneous determination of olanzapine and aripiprazole was developed and validated. Proposed method is the first reported HPLC method that enables the analysis of these two drugs together, in the literature. For a fast and easy optimization, experimental design was employed. Analytes and internal standard were separated in 8 minutes using a monolithic column at optimal conditions. The method was validated in terms of specificity, linearity, accuracy and precision, detection and quantitation limits and robustness. All studies were carried out using spiked human plasma samples to demonstrate the applicability of the method to biological samples. The limits of quantitation for olanzapine and aripiprazole were found $0.069 \mu \mathrm{g} / \mathrm{ml}$ and $0.498 \mu \mathrm{g} / \mathrm{ml}$, respectively. These results demonstrated that the proposed method is suitable for the accurate quantification of the analytes in human plasma at low concentrations. The proposed fast and simple method can be used safely in the routine analysis of olanzapine and aripiprazole.

\section{MATERIALS AND METHODS}

\subsection{Materials}

Olanzapine and carbamazepine were purchased from Sigma-Aldrich (Germany). Aripiprazole was obtained from Santa Cruz Biotechnology. All solvents were HPLC grade from Merck (Germany). Potassium dihydrogen phosphate was from Merck (Germany). Sodium acetate trihydrate, phosphoric acid and acetic acid were from VWR Chemicals. 


\subsection{Preparation of standard solutions and quality control solutions}

Stock solutions of olanzapine $(1.0 \mathrm{mg} / \mathrm{ml})$, aripiprazole $(0.5 \mathrm{mg} / \mathrm{ml})$ and carbamazepine $(1.0 \mathrm{mg} / \mathrm{ml})$ were prepared in methanol individually and stored at $-20^{\circ} \mathrm{C}$. Aliquots of olanzapine and aripiprazole stock solutions were mixed and diluted serially with methanol. Carbamazepine stock solution was also diluted with methanol separately. For investigating matrix effect, standard solutions were prepared by diluting these solutions with water.

Calibration solutions were prepared by spiking serially diluted solutions of analytes and internal standard into drug-free human plasma. Plasma proteins were precipitated with acetonitrile at a ratio of 1 volume sample to 2 volumes acetonitrile. All solutions were vortexed and centrifuged, then clear supernatants were separated and filtered before analysis. At last, calibration standards containing 0.125, 0.250, 0.500, 1.00, 2.00, 4.00, 10.0, 25.0, $50.0 \mu \mathrm{g} / \mathrm{ml}$ olanzapine and aripiprazole were obtained.

Quality control solutions were prepared in the same way as calibration solutions but at different concentrations. Low, middle and high levels of quality control solutions were containing $0.750,6.00$ and 48.0 $\mu \mathrm{g} / \mathrm{ml}$ olanzapine and aripiprazole.

\subsection{Instrumentation and chromatographic conditions}

An HPLC system (Agilent 1290 Infinity) was used during method development. This system was consisted of a binary pump, a degasser, an autosampler, a thermostated column compartment, and a diode array detector. A monolithic column (Chromolith High Resolution, Rp-18, 100-4.6 mm) set at $35^{\circ} \mathrm{C}$ and the mobile phase consisted of phosphate buffer (pH 3.14 and $20 \mathrm{mM})(\mathrm{A})$ and acetonitrile (B) was used for separation. A gradient program that is linear from 20 to $50 \%$ B (in 5 minutes) was employed. Run time was 8 minutes and the column was equilibrated to the starting conditions for 2 minutes. Flow rate was $0.8 \mathrm{ml} / \mathrm{min}$. Carbamazepine was used as internal standard. Detection was performed with diode array detector at $255 \mathrm{~nm}$.

\subsection{Software}

Experimental design study and validation calculations were performed using Microsoft Excel, Minitab 17 and GraphPad Prism 6 programs.

Acknowledgements: This work was supported by Research Council of Anadolu University, Project No: $1705 S 168$. The authors thank Assoc. Prof. Dr. Erol Şener for technical support.

Author contributions: Concept - D.Y.U., S.A.K.; Design - D.Y.U., S.A.K.; Supervision - D.Y.U.; Resource - D.Y.U.; Materials - D.Y.U.; Data Collection and/or Processing - S.A.K.; Analysis and/or Interpretation - S.A.K.; Literature Search - D.Y.U., S.A.K.; Writing - S.A.K.; Critical Reviews - D.Y.U., S.A.K.

Conflict of interest statement: The authors declared no conflict of interest.

\section{REFERENCES}

[1] Konopaske GT, Coyle JT. Schizophrenia. In: Zigmond MJ, Coyle JT, Rowland L. (Eds). Neurobiology of Brain Disorders. Academic Press, San Diego, 2015, pp. 639-654. [CrossRef]

[2] Volk DW, Lewis DA. Schizophreni.In: Rosenberg R, Pascual J. (Eds). Rosenberg's Molecular and Genetic Basis of Neurological and Psychiatric Disease (Fifth Edition). Academic Press, Boston, 2015, pp. 1293-1299. [CrossRef]

[3] Zink M, Englisch S, Meyer-Lindenberg A. Polypharmacy in schizophrenia. Curr Opin Psychiatry. 2010; 23(2): 103111. [CrossRef]

[4] Patteet L, Morrens M, Maudens KE, Niemegeers P, Sabbe B, Neels H. Therapeutic drug monitoring of common antipsychotics. Ther Drug Monit. 2012; 34(6): 629-651. [CrossRef]

[5] Duggal HS. Aripirazole-Olanzapine combination for treatment of schizophrenia. Can J Psychiatry. 2004; 49(2): 151. [CrossRef]

[6] Chen $\mathrm{CH}$, Huang MC, Lu ML. Aripiprazole improves metabolic adversity in olanzapine-treated schizophrenic patients. J Clin Psychopharmacol. 2007; 27(5): 516-517. [CrossRef]

[7] Englisch S, Weinbrenner A, Inta D, Zink M. Aripiprazole for the management of olanzapine-induced weight gain. Pharmacopsychiatry. 2009; 42(04): 166-167. [CrossRef]

[8] Henderson DC, Fan X, Copeland PM, Sharma B, Borba CP, Boxill R, Freudenreich O, Cather C, Evins AE, Goff DC. Aripiprazole added to overweight and obese olanzapine-treated schizophrenia patients. J Clin Psychopharmacol. 2009; 29(2): 165-169. [CrossRef] 
[9] Schönfelder S, Schirmbeck F, Waltereit R, Englisch S, Zink M. Aripiprazole improves olanzapine-associated obsessive compulsive symptoms in schizophrenia. Clin Neuropharmacol. 2011; 34(6): 256-257. [CrossRef]

[10] Aggarwal H, Kumar P. Aripiprazole for olanzapine-induced symptomatic hyperprolactinemia. Indian J Pharmacol. 2010; 42(1): 57-61. [CrossRef]

[11] Patteet L, Cappelle D, Maudens KE, Crunelle CL, Sabbe B, Neels H. Advances in detection of antipsychotics in biological matrices. Clin Chim Acta. 2015; 441: 11-22. [CrossRef]

[12] Dusci LJ, Peter Hackett L, Fellows LM, Ilett KF. Determination of olanzapine in plasma by high-performance liquid chromatography using ultraviolet absorbance detection. J Chromatogr B Analyt Technol Biomed Life Sci. 2002; 773(2): 191-197. [CrossRef]

[13] Olesen OV, Linnet K. Determination of olanzapine in serum by high-performance liquid chromatography using ultraviolet detection considering the easy oxidability of the compound and the presence of other psychotropic drugs. J Chromatogr B Biomed Sci Appl. 1998; 714(2): 309-315. [CrossRef]

[14] Boulton DW, Markowitz JS, DeVane CL. A high-performance liquid chromatography assay with ultraviolet detection for olanzapine in human plasma and urine. J Chromatogr B Biomed Sci Appl. 2001; 759(2): 319-323. [CrossRef]

[15] Musenga A, Saracino MA, Spinelli D, Rizzato E, Boncompagni G, Kenndler E, Raggi MA. Analysis of the recent antipsychotic aripiprazole in human plasma by capillary electrophoresis and high-performance liquid chromatography with diode array detection. Anal Chim Acta. 2008; 612(2): 204-211. [CrossRef]

[16] Lancelin F, Djebrani K, Tabaouti K, Kraoul L, Brovedani S, Paubel P, Piketty ML. Development and validation of a high-performance liquid chromatography method using diode array detection for the simultaneous quantification of aripiprazole and dehydro-aripiprazole in human plasma. J Chromatogr B Analyt Technol Biomed Life Sci. 2008; 867(1): 15-19. [CrossRef]

[17] Shimokawa Y, Akiyama H, Kashiyama E, Koga T, Miyamoto G. High performance liquid chromatographic methods for the determination of aripiprazole with ultraviolet detection in rat plasma and brain: Application to the pharmacokinetic study. J Chromatogr B Analyt Technol Biomed Life Sci. 2005; 821(1): 8-14. [CrossRef]

[18] Wang ST, Li Y. Development of a UPLC-MS/MS method for routine therapeutic drug monitoring of aripiprazole, amisulpride, olanzapine, paliperidone and ziprasidone with a discussion of their therapeutic reference ranges for Chinese patients. Biomed Chromatogr. 2017; 31(8): e3928-n/a. [CrossRef]

[19] Kirchherr H, Kühn-Velten WN. Quantitative determination of forty-eight antidepressants and antipsychotics in human serum by HPLC tandem mass spectrometry: A multi-level, single-sample approach. J Chromatogr B Analyt Technol Biomed Life Sci. 2006; 843(1): 100-113. [CrossRef]

[20] Choong E, Rudaz S, Kottelat A, Guillarme D, Veuthey JL, Eap CB. Therapeutic drug monitoring of seven psychotropic drugs and four metabolites in human plasma by HPLC-MS. J Pharm Biomed Anal. 2009; 50(5): 10001008. [CrossRef]

[21] Uřinovská R, Brozmanová H, Šištík P, Šilhán P, Kacířová I, Lemr K, Grundmann M. Liquid chromatographytandem mass spectrometry method for determination of five antidepressants and four atypical antipsychotics and their main metabolites in human serum. J Chromatogr B Analyt Technol Biomed Life Sci. 2012; 907: 101-107. [CrossRef]

[22] Patteet L, Maudens KE, Sabbe B, Morrens M, De Doncker M, Neels H. High throughput identification and quantification of 16 antipsychotics and 8 major metabolites in serum using ultra-high performance liquid chromatography-tandem mass spectrometry. Clin Chim Acta. 2014; 429: 51-58. [CrossRef]

[23] Hibbert DB. Experimental design in chromatography: A tutorial review. J Chromatogr B. 2012; 910: 2-13. [CrossRef]

[24] Sahu PK, Ramisetti NR, Cecchi T, Swain S, Patro CS, Panda J. An overview of experimental designs in HPLC method development and validation. J Pharm Biomed Anal. 2018; 147: 590-611. [CrossRef]

[25] The International Council for Harmonisation of Technical Requirements for Pharmaceuticals for Human Use (ICH). Validation of analytical procedures: text and methodology, Q2(R1). Harmonized Tripartite Guideline. 2005.

[26] Jancic-Stojanovic B, Malenovic A, Ivanovic D, Rakic T, Medenica M. Chemometrical evaluation of ropinirole and its impurity's chromatographic behavior. J Chromatogr A. 2009; 1216(8): 1263-1269. [CrossRef] 